Безтелесна Л. І., д.е.н., професор, завідувач кафедри трудових ресурсів і підприємництва (Національний університет водного господарства та природокористування, м. Рівне)

\title{
РОТАЦІЯ ЯК РЕЗУЛЬТАТ РЕАЛІЗАЦІЇ ЕФЕКТИВНОГО УПРАВЛІННЯ КОМПЕТЕНЦІЕЮ ЛЮДСЬКИХ РЕСУРСІВ
}

У статті запропоновано використовувати ротацію людських ресурсів для забезпечення конкурентоспроможної діяльності організації (компанії, підприємства) у глобальній економіці. Доведено, що ротації має передувати налагодження ефективного управління, у межах якого відбуватиметься ідентифікація людських ресурсів за їх компетентністю, системні зміни в управлінні та створення центру компетенцій.

Ключові слова: людські ресурси, компетенція, компетентність, кваліфікований спеціаліст, ротація, центр компетенцій.

Постановка наукової проблеми та її значення. Людські ресурси, на відміну від інших, живі істоти, які у виробничому процесі діють усвідомлено. Саме завданням управлінців $€$ створення таких умов діяльності, які б стимулювали людські ресурси до розкриття здібностей і талантів, креативної та інноваційної діяльності.

При реалізації ефективного управлінні людськими ресурсами досягаються хороші результати роботи і продукуються інновації, а їх впровадження дає можливість суб'єктам ринкових відносин бути конкурентоспроможними у сучасній глобальній економіці. Досягнення високої конкурентоспроможності вимагає від менеджерів 3 управління людськими ресурсами реалізації цілого ряду процедур, зокрема, й управління їх рухом. Це актуалізується в сучасних умовах демографічної кризи, величезного розриву у рівнях заробітної плати на національному ринку праці та європейському, високій мобільності людських ресурсів та трансформації стандартного формату організації соціально-трудових відносин. За таких умов лише внутрішньо організаційне ефективне управління залученими людськими ресурсами дає право досягнути бажаного результату.

Аналіз останніх публікацій. Проблематиці ефективного управління присвячено безліч праць як зарубіжних, так і вітчизняних вчених. Але і до тепер ця проблема не $\epsilon$ вирішеною остаточно. Варто зауважити, що Прахалада і Гері Хемел [1, С. 257-258] стверджують, що для керівників багатьох компаній і до тепер неочевидно 
як досягати успіху серед конкурентів у всьому світі. У своїй праці вони доводять про необхідність формування ключової компетенції корпорації, яка допомагає досягти успіху компанії у конкурентному світі. Проте, при цьому зауважують, що керівництво повинно розглядати компанію не як збір декількох стратегічних бізнес одиниць, а як поєднання ключових компетенцій - знань про те, як управляти різними виробничими навиками та технологіями. Саме власниками навиків $€$ людські ресурси.

У вітчизняній науці ця проблематика розглядається з позицій людських ресурсів на макро, мезо і мікро (підприємницькому) рівні та за трьома напрямами. Перший, соціально-економічний доводить, що конкурентоспроможність, власне, людських ресурсів реалізується та ринку праці. Його представниками $є$ Л.І. Бетелесна, О.С. Пляшко [2, С. 96-97], І.Л. Петрова [3], Е.С. Шилець [4] та ін. Другий, управлінський акцентує увагу на показниках вимірювання та траєкторіях руху персоналу (Ж.М. Балабанюк [5], В.Г. Никифоренко [6, С. 120] та ін.). Третій, економіко-управлінський акцентує увагу на сутності компетенцій та факторах їх формування у працівників підприємств [7], як ключовому елементі управління людським капіталом організації [8], а також безперервному розвитку компетентностей для процесу управління талантами високотехнологічних підприємств в Україні [9, C. 15].

Принагідно зауважимо, що зарубіжні автори, зокрема, А.Я. Кібанов пропонує компетенцію розглядати як об'єкт стратегічного управління [10], а А.О. Арефьєв, А.Д. Баженов дають практичні поради як управляти компетенцією і здійснювати ротацію людських ресурсів проектно-орієнтованого підприємства [11]. Утім, незважаючи на широту підходів до розкриття цієї тематики, вона не є вичерпно розкрита і залишає поле для наукових розвідок і $€$ доволі актуальною.

Метою досліддження $є$ обгрунтування необхідності проведення ротації на основі ефективного управління компетенцією людських ресурсів та виконання певних умов задля їх утримання та досягнення конкурентоспроможної діяльності організації, підприємства, компанії та ін.

Виклад основного матеріалу дослідження. Основною функціональною ознакою людських ресурсів $€$ їх участь в процесі праці. Окрім того, людські ресурси - це потенційні активи, які в майбутньому здатні примножувати додану вартість. М. Армстронг визнає людей найбільш цінним активом організації, оскільки саме вони здатні колективно та індивідуально вносити вклад у досягнення їі цілей [13, C. 6]. При цьому поняття активу більшою мірою стосується продуктивних можливостей людей створювати інновації і забезпечувати організаціям неповторювані конкурентні переваги та синергетичні ви- 
годи (наприклад, гудвіл). 3 огляду на роль та можливості людських ресурсів у процесі виробництва роботодавці намагаються не лише формувати компетенції людських ресурсів, але й ефективно управляти ними.

Глобалізація стимулює вільне переміщення робочої сили і капіталу в місця зі сприятливими умовами та зумовлює нові способи взаємодії. Проте компаніям стає дедалі складніше залучати, розвивати й утримувати талановитих співробітників, про що свідчать результа-

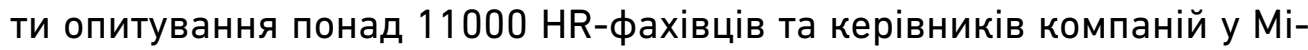
жнародному дослідженні Deloitte «Тенденції у сфері управління персоналом - 2018». У ході опитування було виявлено що управління трудовими ресурсами виходить за рамки корпорації. Так, 65\% респондентів світу (78\% по України) вважають даний тренд важливим для своїх організацій [14]. Результати опитування довели, що сучасна робоча сила перетворилася на динамічну екосистему, а їі склад суттєво змінюється. Сьогодні екосистема трудових ресурсів охоплює штатних працівників, партнерів, контракторів, фрілансерів, гігпрацівників, які не прив'язані до конкретного роботодавця, тимчасово або постійно працюють на кілька організацій одночасно, самостійно обирають проекти, та людей, які працюють за принципом краудворкінгу (тобто зосереджуються на реалізації конкретних проектів і завдань) [14].

Саме за таких умов лише ефективне управління компетенцією людських ресурсів дає можливість організації бути конкурентоспроможною в умовах глобалізації.

Під компетенцією людських ресурсів розуміємо сукупність знань, навиків і особистих якостей, які дозволяють їм вирішувати відповідні завдання (чи сукупність завдань). Компетенція описується у формі переліку вимог до знань, навиків і якостей співробітників для функцій, посадових обов'язків чи ролі в проекті. Якщо професійні навики, знання і особисті якості спеціаліста співпадають з вимогами до компетенції для певної посади, чи завдання, то відповідна робота, при інших рівних умовах, може виконуватися таким спеціалістом якісно та ефективно. Проте, компетенція людських ресурсів не $\epsilon$ тотожною компетентності [7; 11]. Автори [11] стверджують, що кваліфікація тотожна компетентності і розуміють під нею ступінь розвинутості у спеціаліста певних компетенцій (першу чергу - в сфері знань і навичок). Чим вищою $є$ компетентність, тим швидше і якісніше виконує працівник роботу в межах своїх компетенцій. Окрім того, варто серед працівників виокремлювати категорію ключовий спеціаліст - це той працівник, що володіє глибокими знаннями у певній професійній сфері і застосовує їх переважній більшості проектів організації, проте без його залучення до проекту він не буде успішним. Саме організації найбільш зацікавлені в утриманні таких працівників. 
Варто зауважити, що категорія ключових фахівців має певні особливі характеристики.

По-перше, пріоритетом їх у мотивації $€$ негрошові мотиви. Головний мотив для них - це не досягнення результату, а сам процес праці, постійне підняття рівня власного професіоналізму на новий рівень, прагнення до здобуття статуту «найпрофесійніший», хороші і комфортні умови праці, а серед грошових мотивів - висока гарантована заробітна плата, а не премії за отриманий результат проекту.

По-друге, унікальна компетентність спеціалістів в багатьох ситуаціях формує в багатьох з них певну лінію поведінки їхньої нзамінності та бажання різними шляхами цю незамінність зберегти 3 метою невтрати здобутий статус. Такий статус дає можливість таким працівникам диктувати умови як фінансового, так і інщого характеру, а інколи за дороговизни проекту, навіть шантажувати компанію. 3 метою збереження такого статусу ці працівники відмовляються навчати інших, пояснювати передумови прийняття тих чи інших рішень, документувати знання.

По-третє, висока кваліфікація працівників часто супроводжується низькою мотивацією до спілкування та нерозвинутими комунікаційними і соціальними навиками. Захоплюючись процесом роботи, такі працівники відчувають дискомфорт, коли їм приходиться вирішувати поточні завдання сумісно з кимось, окрім свої колег, а тим більше з клієнтами.

Звісно, що реалізація одночасно декількох проектів в організації обумовлює необхідності вирівнювання ресурсів за рахунок переміщення, ротації ключових спеціалістів (висококваліфікованих людських ресурсів) і досить часто виникають збої (проблеми), які відсутні при переміщенні обладнання, сировини, матеріалів чи навіть некваліфікованого персоналу (співробітників робітничих спеціальностей), тому що управління людськми ресурсами супроводжується не лише емоціями, але й реакцією на впровадженні чи скоріше невпровадженні інструменти у межах реалізації управлінських заходів і рішень, що реалізуються в межах кадрової політики організації.

У найзагальнішому переміщення працівників в середині організації трактується як рух. Проте, внутрішньоорганізаційний рух персоналу, що здійснюватися по горизонталі трактується як ротація, що передбачає збереження рівня займаної посади. Звісно, що ротація має наслідки як позитивні, так і негативні. До позитивних наслідків можна віднести задоволення потреби працівника у відповідних умовах праці, бажанні працювати поруч із друзями, членами родини, більш змістовного трудового процесу, що, у кінцевому рахунку, веде до підвищення ефективності його праці, а до негативних зниження продуктивності в період адаптації працівника, порушення сформованої у колективі системи комунікацій [6, С. 120]. 
Серія «Економічні науки»

Випуск 4(84) 2018 р.

Використання ротації потребує ефективного управління компетенціями людських ресурсів і вимагає реалізації не локальних, а системних змін в управлінні організацією. Вони поширюються на систему стимулювання, навчання, загальнокорпоративного планування і головне корпоративниої культури. Проте, в організаційному плані у компаніях мають створюватися Центр компетенцій [11].

Центр компетенцій - це своєрідна структура в середині компанії з трансферту компетенцій від ключових спеціалістів до тих, що стикаються 3 їх недостатністю. Головним завданням його діяльності $\epsilon$ створення бази даних ключових компетенцій та налагодження каналів їх передачі. Окрім того, необхідними завданнями до виконання $\epsilon$ :

- оцінка співробітників з недостатністю компетенцій у розрізі: результатів роботи, знань, потенціалу та мотивації;

- формування учбових матеріалів та програм;

- формування планів завантаження та розвитку обох груп спеціалістів;

- перегляду існуючої системи мотивації ключових спеціалістів.

Успішна діяльність центру потребує внесення таких змін в систему стимулювання ключових спеціалістів.

Для кожного з них повинна бути розроблена індивідуальна система. При її розробці обов'язково має бути залучений безпосередній керівник ключового спеціаліста. Окрім того, індивідуальна програма повинна постійно переглядатися з врахуванням факторів, серед яких плани компанії, потреби праціваника, стан ринку праці та інші.

Система стимулювання кожного ключового спеціаліста повинна містити винагородження (моральне і/чи матеріальне - визначається індивідуально) за документування знань і навчання інших. Так, вартість години роботи з колегами має бути значно вищою, а ніж робота за спеціальністю. А також мають бути передбачені виплати за організацію роботи стажерів, а також за позитивні результати роботи стажерів в інших проектах куди вони були спрямовані планово або ж в процесі вирівнювання ресурсів.

Окрім того, загальнокорпоративна система стимулювання і корпоративна культура компанії повинні передбачати привабливість статусу «ключовий спеціаліст» як з матеріальної, так із моральної сторони престижу. Це мотивуватиме молодих спеціалістів до розвитку в рамках компанії та участі в програмах стажування і навчання в Центрах компетенцій у ключових спеціалістів.

Висновки 3 проведеного дослідження. Реалізація запропонованого підходу до управління комтенцією людських ресурсів в організації $\epsilon$ передумовою до здійснення ефективних ротацій в середині підприємства. Звичайно, що це вимагає впровадження цілої низки управлінських рішень, що мають бути спільно ініційовані відділом 3 управління людськими ресурсами (персоналом) та топ- 
менеджментом.

Головним у реалізації пропонованого є створення такої внутрішньо організаційної системи управління людськими ресурсами на основі їх компетенцій, яка б могла швидко реагувати на зовнішні виклики та забезпечувати можливість організації бути конкурентоспроможною у глобальній економіці.

1. Управление бизнесом / пер. с англ. Серия «Harvard Business Review: 10 лучших статей» М. : Лльпина Паблишер, 2016. 250 с. 2. Безтелесна Л. І., Пляшко О. С. Теоретичні основи трактування потенційної та реальної конкурентоспроможності людських ресурсів. Формування ринкової економіки. Праця в XXI столітті: новітні тенденції, соціальний вимір, інноваційний розвиток : зб. наук. пр. У 2 т. К. : КНЕУ, 2012. Т. 1. Спец. вип. С. 93-103. 3. Петрова І. Л. Сегментація ринку праці: теорія і практика регулювання. К. : Ін-т економіки, управління та господарського права, 1997. 298 с. 4. Шилец Е. С. Конкурентоспособность человеческих ресурсов в системе трудовых отношений в условиях глобального кризисна. Вісник Донецького університету. Економіка $і$ право. 2011. Сер. В., Т. 1. Спецвипуск. С. 176-179. 5. Балабанюк Ж. М. Аналіз показників руху персоналу. Ефективна економіка. 2011. № 8. 6. Никифоренко В. Г. Управління персоналом : навч. посібник. 2-ге видання, виправлене та доповнене. Одеса : Атлант, 2013. 275 с. 7. Михайляк Г. В. Сутність компетенцій та фактори їх формування у працівників підприємств. Вісник Національного університету "Львівська політехніка". Менеджмент та підприємництво в Україні: етапи становлення і проблеми розвитку. 2012. C. 94-101. Lviv Polytechnic National University Institutional Repository URL: http://ena.lp.edu.ua (дата звернення: 15.05.2019). 8. Волобоєва І. О. Компетенції: ключовий елемент управління людським капіталом організації. Соціально-трудові відносини: теорія та практика. 2014. № 2. С. 223-228. URL: http://nbuv.gov.ua/UJRN/stvttp_2014_2_33 (дата звернення: 15.05.2019). 9. Герасименко Г. В. Ефективність управління людськими ресурсами високотехнологічних підприємств: соціально-трудовий вимір та механізми підвищення : автор. дис. ... канд. економ. наук : 08.09.01 Київ. 2019. 25 с. 10. Управление персоналом организации : учебник / под ред. проф. А. Я. Кибанова. М. : ИНФРА-М, 1997. 512 с. 11. Арефьев А. О., Баженов А. Д. Управление компетенцией и ротация человеческих ресурсов проектноориентированного предприятия. URL: https://blog.iteam.ru/upravleniekompetentsiej-i-rotatsiya-chelovecheskih-resursov-proektno-

orientirovannogo-predpriyatiya/ (дата звернення: 15.05.2019). 12. Армстронг М. Практика управления человеческими ресурсами / пер. с англ. 8-е изд. СПб. : Питер, 2007. 832 с. 13. Тенденції у сфері управління персоналом - 2018. URL: https://www2.deloitte. com/ua/uk/pages/human capital/articles/human-capital-trends-2018.html (дата звернення: 15.05.2019). 


\section{REFERENCES:}

1. Upravlenie biznesom / per. s anhl. Seriia «Harvard Business Review: 10 luchshikh statei» M. : Llpina Pablisher, 2016. 250 s. 2. Beztelesna L. I., Pliashko 0. S. Teoretychni osnovy traktuvannia potentsiinoi ta realnoi konkurentospromozhnosti liudskykh resursiv. Formuvannia rynkovoi ekonomiky. Pratsia v KhKhl stolitti: novitni tendentsii, sotsialnyi vymir, innovatsiinyi rozvytok: zb. nauk. pr. U 2 t. K. : KNEU, 2012. T. 1. Spets. vyp. S. 93-103. 3. Petrova I. L. Sehmentatsiia rynku pratsi: teoriia i praktyka rehuliuvannia. K. : In-t ekonomiky, upravlinnia ta hospodarskoho prava, 1997. 298 s. 4. Shylets E. S. Konkurentosposobnost chelovecheskikh resursov $\mathrm{v}$ sisteme trudovykh otnoshenii $v$ usloviiakh hlobalnoho krizisna. Visnyk Donetskoho universytetu. Ekonomika i pravo. 2011. Ser. V., T. 1. Spetsvypusk. S. 176-179. 5. Balabaniuk Zh. M. Analiz pokaznykiv rukhu personalu. Efektyvna ekonomika. 2011. № 8. 6. Nykyforenko V. H. Upravlinnia personalom : navch. posibnyk. 2he vydannia, vypravlene ta dopovnene. Odesa : Atlant, 2013. 275 s. 7. Mykhailiak H. V. Sutnist kompetentsii ta faktory yikh formuvannia u pratsivnykiv pidpryiemstv. Visnyk Natsionalnoho universytetu "Lvivska politekhnika". Menedzhment ta pidpryiemnytstvo v Ukraini: etapy stanovlennia i problemy rozvytku. 2012. S. 94-101. Lviv Polytechnic National University Institutional Repository. URL: http://ena.lp.edu.ua (data zvernennia: 15.05.2019). 8. Voloboieva I. O. Kompetentsii: kliuchovyi element upravlinnia liudskym kapitalom orhanizatsii. Sotsialno-trudovi vidnosyny: teoriia ta praktyka. 2014. № 2. S. 223-228. URL: http://nbuv.gov.ua/

UJRN/stvttp_2014_2_33 (data zvernennia: 15.05.2019). 9. Herasymenko H. V. Efektyvnist upravlinnia liudskymy resursamy vysokotekhnolohichnykh pidpryiemstv: sotsialno-trudovyi vymir ta mekhanizmy pidvyshchennia : avtor. dys. ... kand. ekonom. nauk : 08.09 .01 Kyiv. 2019. 25 s. 10. Upravlenie personalom orhanizatsii : uchebnik / pod red. prof. A. Ya. Kibanova. M. : INFRAM, 1997. 512 s. 11. Arefev A. O., Bazhenov A. D. Upravlenie kompetentsiei i rotatsiia chelovecheskikh resursov proektno-orientirovannoho predpriiatiia. URL: $\quad$ https://blog.iteam.ru/upravlenie-kompetentsiej-i-rotatsiyachelovecheskih-resursov-proektno-orientirovannogo-predpriyatiya/ (data zvernennia: 15.05.2019). 12. Armstronh M. Praktika upravleniia chelovecheskimi resursami / per. s anhl. 8-e izd. SPb. : Pyter, 2007. 832 s. 13. Tendentsii u sferi upravlinnia personalom - 2018. URL: https://www2.deloitte. com/ua/uk/pages/human -capital/articles/humancapital-trends-2018.html (data zvernennia: 15.05.2019).

Рецензент: д.е.н., професор Савіна Н. Б. (НУВГП)

Beztelesna L. I., Doctor of Economics, Professor, Head of the Department of Labor Resources and Entrepreneurship (National University of Water and Environmental Engineering, Rivne)

ROTATION AS A RESULT OF THE IMPLEMENTATION OF THE EFFECTIVE MANAGEMENT OF THE HUMAN RESOURCES COMPETENCE 
The article substantiates that human resources, participating in the production process, operate functionally and consciously. In addition, human resources are potential assets of the organization (companies, enterprises) and can produce innovations. However, if necessary, the movement of human resources arises, on the other, from other resources of the problem. It is proved that it is necessary to distinguish between the concept: competence, competence and qualification of human resources. Actually, in order to avoid production problems in the performance of tasks, it is proposed to identify employees of the enterprise by the level of competence and transfer competence from qualified specialists to those with a deficit of competencies. It is proposed to create a competence center. It is proved that the clustered specialists have certain characteristics that must be taken into account when organizing the center's activities, as well as make changes to the system of stimulation, planning, corporate culture. The proposed rotation of human resources is considered an indicator of effective management of competencies in the organization.

Keywords: human resources, competency, competence, qualified specialist, rotation, competence center.

Безтелесна Л. И., д.э.н., профессор, заведующая кафедрой трудовых ресурсов и предпринимательства (Национальный университет водного хозяйства и природопользования, г. Ровно)

РОТАЦИЯ КАК РЕЗУЛЬТАТ РЕАЛИЗАЦИИ ЭФФЕКТИВНОГО УПРАВЛЕНИЯ КОМПЕТЕНЦИЕЙ ЧЕЛОВЕЧЕСКИХ РЕСУРСОВ

В статье предложено использовать ротацию человеческих ресурсов для обеспечения конкурентоспособной деятельности организации (компании, предприятия) в глобальной экономике. Доказано, что ротации должно предшествовать налаживание эффективного управления, в рамках которого будет происходить идентификация человеческих ресурсов по их компетентности, системные изменения в управлении и создания центра компетенций.

Ключевые слова: человеческие ресурсы, компетенция, компетентность, квалифицированный специалист, ротация, центр компетенции. 